\title{
HIV/AIDS infection in Ukraine: a review of epidemiological data
}

\author{
Larissa Burruano \\ From $16^{\text {th }}$ International Symposium on HIV and Emerging Infectious Diseases \\ Marseille, France. 24-26 March 2010
}

\section{Background}

To better understand the HIV dynamic in Ukraine in order to adapt HIV control efforts accordingly. The number of newly diagnosed HIV infections in Ukraine ranks second in the WHO European Region after the Russian Federation according to the end-year report 2006 of the European Centre for the Epidemiological Monitoring of AIDS (EuroHIV). According to the Ukrainian Ministry of Health the cumulative number of reported HIV infections by the end of 2008 amounts to more than 140.000 cases. However, because of many unreported cases the actual figures are supposed the official reports considerably.

\section{Methods}

Reported HIV/AIDS cases from the official epidemiological register of the Ukrainian Centre for AIDS Prevention between 1987 and 2008 were analysed. Joint United Nations Programme on HIV/AIDS country fact sheets were reviewed and analysed and this information was supplemented with published HIV prevalence and sexually transmitted disease case reporting information.

\section{Results}

Between 1987 and 2000, 36,600 Ukrainian citizens were registered with HIV. The number of officially registered HIV-infections increased from 7,000 in 2001 to 18,963 in $2008.7,009$ new infections were due to IDU, 7,880 to heterosexual contact and 3,635 to vertical transmissions from HIV infected mothers to their children, Table 1.

\section{Discussion}

The Ukraine is one of the European countries with the most rapidly increasing number of newly diagnosed HIV cases, mainly transmitted through IDU, but also increasingly through heterosexual contact in the general population and mother-to-child-transmission. In order to protect people from HIV infection, it is important to find ways to empower them by implementing policies and specific prevention measures that increase their access to knowledge about the HIV/ AIDS epidemic. Free HIV tests, programs for the prevention the mother's child transference, information and access to condoms, clean hypodermic needles, drugs sentence programs and a medical treatment of

Table 1 Newly diagnosed HIV infections, AIDS cases and AIDS deaths in Ukraine, 1987-2008

\begin{tabular}{|c|c|c|c|c|c|c|c|c|c|}
\hline & $1987-2000^{*}$ & 2001 & 2002 & 2003 & 2004 & 2005 & 2006 & 2007 & 2008 \\
\hline \multicolumn{10}{|l|}{ New HIV infections } \\
\hline New HIV infections in total & 36600 & 7000 & 8756 & 10009 & 12491 & 13770 & 16078 & 17669 & 18963 \\
\hline \multicolumn{10}{|l|}{ AIDS } \\
\hline AIDS cases & 2040 & 867 & 1353 & 1915 & 2743 & 4217 & 4723 & 4573 & 4380 \\
\hline Deaths among AIDS cases & 1000 & 473 & 834 & 1285 & 1775 & 2188 & 2416 & 2507 & 2710 \\
\hline
\end{tabular}

${ }^{*}$ Cumulative HIV new infections since 1987

Correspondence: dr.burruano@web.de

CompNet, Clinic for Dermatology and Allergology, Ruhr-University, Bochum,

Germany 
gender illness would be important measures for the prevention and health care [1].

Published: 11 May 2010

\section{Reference}

1. Burruano L, Seydel J: Die Ausbreitung von HIV/Aids in der Ukraine. [The Spread of HIV/AIDS in Ukraine]. Gesundheitswesen 2006, 68:571-574.

doi:10.1186/1742-4690-7-S1-P1

Cite this article as: Burruano: HIV/AIDS infection in Ukraine: a review of epidemiological data. Retrovirology 2010 7(Suppl 1):P1.

Submit your next manuscript to BioMed Central and take full advantage of:

- Convenient online submission

- Thorough peer review

- No space constraints or color figure charges

- Immediate publication on acceptance

- Inclusion in PubMed, CAS, Scopus and Google Scholar

- Research which is freely available for redistribution

Submit your manuscript at www.biomedcentral.com/submit 